\title{
In vitro mycorrhization of micropropagated Helianthemum almeriense plantlets with Terfezia claveryi (desert truffle)
}

\author{
Maria Asunción Morte, Antonio Cano, Mario Honrubia and Pilar Torres
}

Morte, M. A., Cano, A., Honrubia, M. \& Torres, P. 1994. In vitro mycorrhization of micropropagated Helianthemum almeriense plantlets with Terfezia claveryi (desert truffle). Agricultural Science in Finland 3: 309-314. (Dpto. Biología Vegetal (Botánica), Facultad de Biología, Universidad de Murcia, Campus de Espinardo, Murcia, España.)

The mycorrhizal synthesis of Terfezia claveryi with micropropagated plantlets of Helianthemum almeriense was carried out in vitro on modified Modified MelinNorkrans (MMN) agar medium with $\mathrm{pH}$ 8.0. The mycorrhization rate was about $80 \%$ after 12 weeks. T. claveryi formed ectendomycorrhizas without hyphal mantle. The effect of the fungus on in vitro rooting was also studied. T. claveryi did not enhance in vitro rooting of microcuttings of $H$. almeriense. In vitro survival of the plantlets was the limiting step and mycorrhizal inoculation appeared to improve the survival rate of rooted plantlets. The effect of the mineral composition and $\mathrm{pH}$ of the medium on survival are discussed.

Key words: micropropagated Cistaceae plantlets, in vitro synthesis

\section{Introduction}

Helianthemum almeriense Pau belongs to the Cistaceae and is one of the most abundant shrubs of the semi-arid areas in Spain. This species, which is of great interest for reafforestation, establishes ecto-endomycorrhizae with Ascomycetes such us Terfezia sp. and Balsamia sp. (desert truffles).

Terfezia claveryi is a hypogeous fungus found in marl-gypsum soils under $H$. almeriense and in marl calcareous and sandy soils under $H$. almeriense and $H$. lavandulifolium in the region of Murcia (HonRuBia et al. 1992). This fungus, called "turma" in Spanish semi-arid zones, is well adapted to the xeric conditions of the Southern Mediterranean area, where it is prized and is of marked gastronomic and economic importance.

We report here the first in vitro mycorrhiza- tion of micropropagated $H$. almeriense plantlets with Terfezia claveryi .

\section{Material and methods}

\section{Plant material}

$H$. almeriense plants were micropropagated following the procedure described by MORTE and HonRubia (1992). After 4 weeks, plantlets for experiments were collected from the rooting medium of MURASHIGE and SKOOG (1962) with salt strength diluted to $1: 4$, without auxins.

At inoculation, each rooted plantlet had a shoot length of about $3 \mathrm{~cm}$, and four to five nodal segments with two leaves each. The average number of roots per plantlet was three. They were un- 


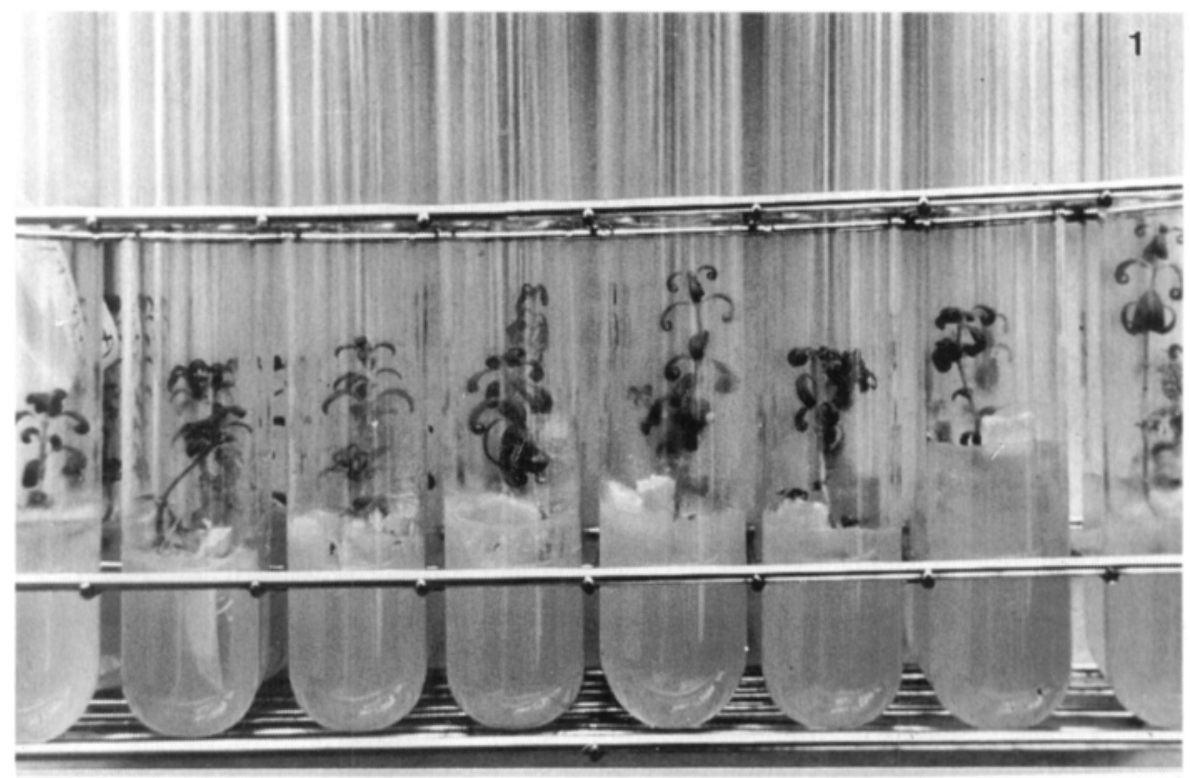

Fig. 1. In vitro system for inoculating micropropagated $H$. almeriense plantlets with $T$. claveryi, on a modified MMN medium. (Photo: M.A. Morte)

ramified, with lengths ranging from 1 to $1.5 \mathrm{~cm}$. These plantlets were called $\mathrm{R}+$ to differentiate them from unrooted explants with the same shoot characteristics called $\mathrm{R}-$.

Cultivation conditions throughout the process of micropropagation were $25 \pm 2^{\circ} \mathrm{C}, 40 \mu \mathrm{mol} \cdot \mathrm{m}^{-2} \cdot \mathrm{s}^{-1}$ Growlux fluorescent light and 16-h photoperiod. These culture conditions were maintained for the mycorrhizal synthesis experiments, too.

\section{Fungal material}

Isolates of T.claveryi were obtained from fruitbody tissues. The best growth medium was the Modified Melin-Norkrans (MMN) agar medium (MARX 1969) (in mg.l ${ }^{-1}$; ClCa 50; ClNa 25; $\mathrm{PO}_{4} \mathrm{H}\left(\mathrm{NH}_{4}\right)_{2} 250 ; \mathrm{MgSO}_{4} .7 \mathrm{H}_{2} \mathrm{O} 150 ; \mathrm{Cl}_{3} \mathrm{Fe} 1 \%$; thiamine- $\mathrm{HCl} 100$ ) with glucose $10 \mathrm{~g} . \mathrm{l}^{-1}$, malt $3 \mathrm{~g} . \mathrm{l}^{-1}$ and solidified with $15 \mathrm{~g} . \mathrm{l}^{-1}$ of agar and pH 8.0.

\section{Experiments}

Two kinds of substrate were used for the in vitro inoculation of $H$. almeriense with $T$. claveryi:
1) A sterilized mixture of vermiculite: peat ( $2: 1$, v/v) watered with MMN liquid medium with

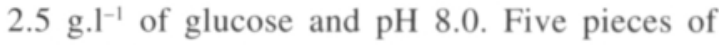
agar, $0.25 \mathrm{~cm}^{2}$ in surface, with mycelium of T. claveryi grown on a modified MMN (MMN nutrients less malt and $\left.\mathrm{PO}_{4} \mathrm{H}\left(\mathrm{NH}_{4}\right)_{2}\right)$ liquid medium with $2.5 \mathrm{~g} . \mathrm{l}^{-1}$ of sucrose were used as inoculum. The rooted plantlets obtained on the MS/4 medium were cultivated with the mycelium and $100 \mathrm{ml}$ of substrate in Erlenmeyer flasks of $250 \mathrm{ml}$. The experiments were repeated three times with 20 inoculated and 20 control plantlets each time.

2) Modified MMN medium with 8 g. $\mathrm{l}^{-1}$ of agar and $2.5{\mathrm{~g} . \mathrm{l}^{-1}}^{-1}$ of glucose, $\mathrm{pH}$ 8.0. Pieces of agar, $0.25 \mathrm{~cm}^{2}$ in surface, with mycelium of $T$. claveryi grown on MMN medium (15 g. $\mathrm{l}^{-1}$ of agar and $\mathrm{pH}$ 8.0 ) were used as inoculum. To facilitate the inoculation process and to see the effect of this fungus on rooting, rooted plantlets $(\mathrm{R}+)$ and unrooted microcuttings $(\mathrm{R}-)$ were inoculated with two pieces of agar with mycelium per tube. The tubes had a diameter of $2.5 \mathrm{~cm}$ and were $20 \mathrm{~cm}$ long. $25 \mathrm{ml}$ of medium per tube was used (Fig. 1). The experiments were repeated twice, 


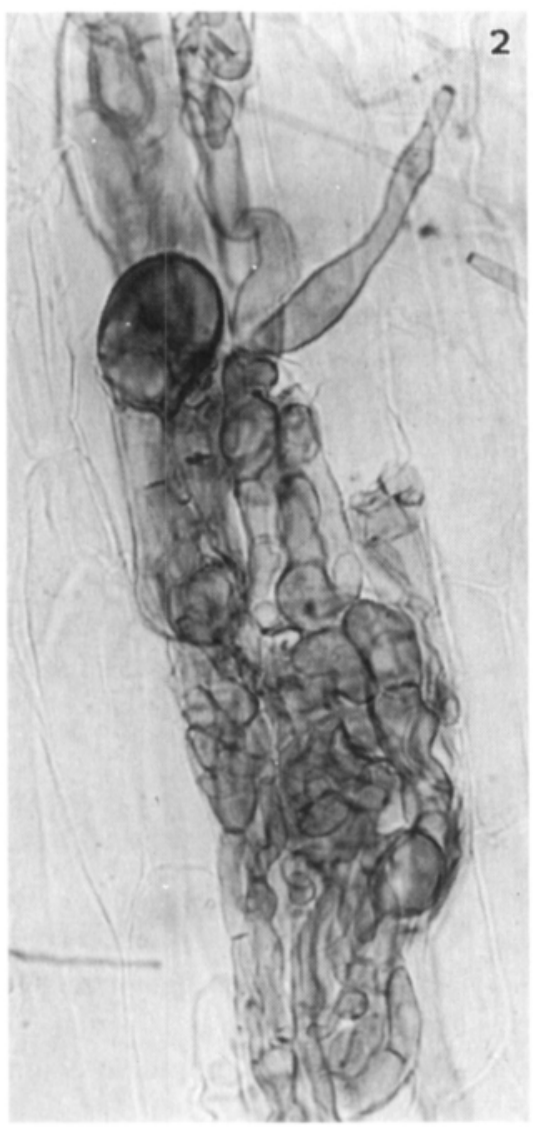

Fig. 2. Longitudinal section of infected root; the hyphae form coils that fill the host cells, showing a bead shape. 40 x. (Photo: M.A. Morte)

with 15 plantlets or explants being used for each treatment each time.

Fungal colonization was assessed on cleared and stained root samples (PHILLIPS and HAYMAN 1970). The percentage of root infection was estimated according to the grid-line intersect method (Giovannettr and Mosse 1980).

\section{Results and discussion}

\section{Experiment 1}

The mycelium grew and had colonized the whole substratum after just four weeks. Plantlets elongation was clearly visible after the same period

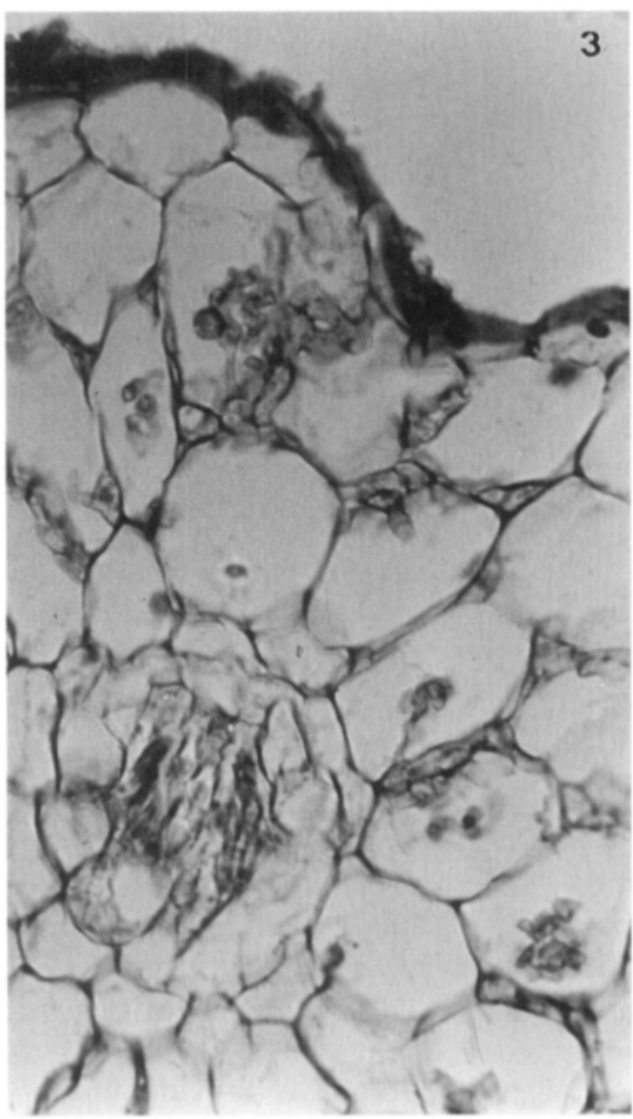

Fig. 3. Cross-section showing absence of hyphal mantle, and inter- and intracellular infections affecting only the cortical cells. 40 x. (Photo: M.A. Morte)

of time. However, no mycorrhization was observed 2, 4 and 6 months after inoculation. The survival rate of the plantlets after 24 weeks in vitro was almost the same (about $80 \%$ ) for both the control and inoculated plantlets.

We consider it probable that plantlets did not form mycorrhizas because the substrate used was very rich in nutrients.

\section{Experiment 2}

\section{Rooting:}

In comparison with plantlets rooted on MS/4 medium (MorTe and Honrubia 1992), the rooting rate of explants within the first 4 weeks of cul- 


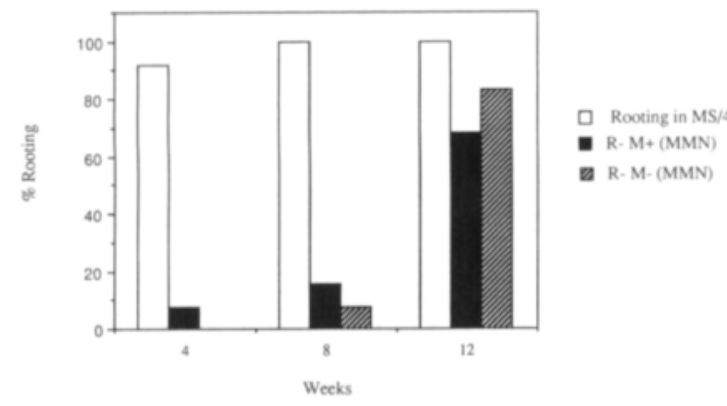

Fig. 4. Rooting percentage of $H$. almeriense microcuttings grown on $\mathrm{MS} / 4$ and $\mathrm{MMN}$ media and inoculated with $T$. claveryi.

ture on MMN was low (Fig. 4). In vitro rooting of explant is a complex process that can be influenced by many factors (PIERIK 1987). One of the factors causing the low rooting rate in our experiments may have been the carbon source. It has been firmly established that sugar is necessary for adventitious root formation (PIERIK 1987). The kinds of carbohydrates and their concentrations also influence rooting (Moncousin et al. 1992, UOSUKAINEN 1992, CABONI et al. 1992). Generally, sucrose and glucose, both at low concentrations (10-20 g. $\left.\mathrm{l}^{-1}\right)$, are the most effective carbon sources for rooting (CHALUPA 1977, CHENG and Voqui 1977, Timmis and Ritchie 1984). Our experiments suggest that the kind of sugar (glucose) and the low concentration $\left(2.5{\left.\mathrm{~g} . \mathrm{l}^{-1}\right)}^{-1}\right.$ used were not conducive to rooting. Also mineral nutrients may have affected rooting, since the MMNmodified medium we used contains few mineral nutrients, and they are at lower concentrations than in the MS medium.

In this specific, and probably not optimal, nutrient context, the presence of the mycorrhizal fungus $T$. claveryi did not improve rooting of the explants (Fig. 4). IAA release of $T$. claveryi was not investigated but, if present IAA production under our experimental conditions but if any, this did not enhance in vitro rooting of the $H$. almeriense cuttings.

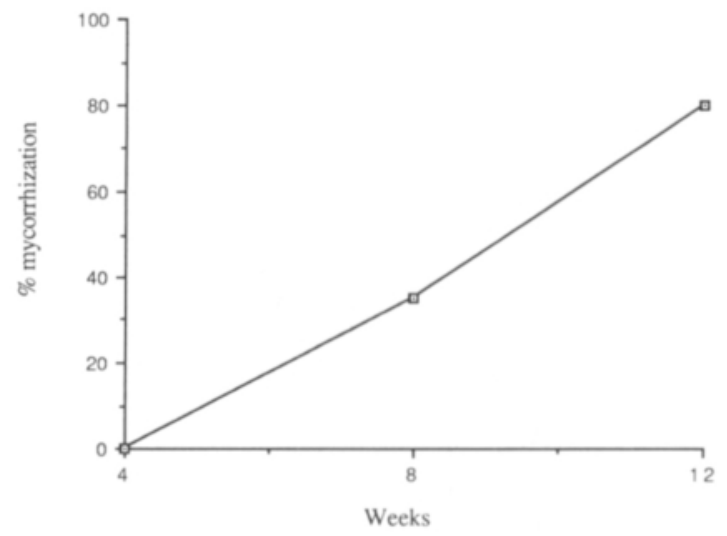

Fig. 5. In vitro mycorrhization percentages of $\mathrm{R}+\mathrm{M}+$ plantlets.

\section{Mycorrhization:}

The mycelium grew from the surface of the inoculum into the substrate within 4 weeks. This mycelial growth into the agar may have been due either to the fact that Terfezia is a hypogeous fungus or to the different agar concentrations ( $8 \mathrm{~g} . \mathrm{l}^{-1}$ in the tube and $15 \mathrm{~g} . \mathrm{l}^{-1}$ for the pieces of inoculum). It allowed the fungus to colonize the root system very well.

Until the $4^{\text {th }}$ week, no mycorrhization was observed, only some infection points were visible. After 8 weeks, the mycorrhization rate was $35 \%$ and it increased to $80 \%$ after 12 weeks (Fig. 5). The newly produced roots of $\mathrm{R}-\mathrm{M}+$ microcuttings were very short $(0.1-0.3 \mathrm{~cm})$, with an average of five roots/explant, and did not form mycorrhizas.

Using non-micropropagated plants of Helianthemum guttatum and a substrate of perlite watered with a nutrient solution, ForTAS and CHEVALIER (1992) obtained mycorrhizas of Terfezia under axenic conditions. ROTH-BEJERANO et al. (1990) also obtained mycorrhizas with seedlings of Helianthemum sessiliflorum and Terfezia leonis in a half-strength Hoagland's solution with agar and activated charcoal.

The morphology of the mycorrhizas formed in our experiments was similar to that of the ectendomycorrhizas described by FORTAS and CHEVALIER (1992). Both the extramatricial and intercel- 


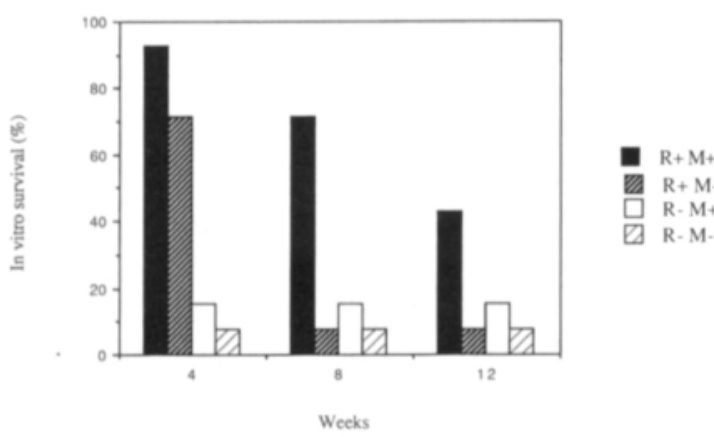

Fig. 6. In vitro survival percentages of mycorrhizal $(\mathrm{R}+\mathrm{M}+)$ $(\mathrm{R}-\mathrm{M}+)$ and non mycorrhizal $(\mathrm{R}+\mathrm{M}-)(\mathrm{R}-\mathrm{M}-)$ plantlets or microcuttings grown on an $\mathrm{MMN}$ modified medium.

lular hyphae were moniliform or beadlike. The intracelullar hyphae formed coils which filled the whole lumen (Fig. 2).

Hyphal mantle was absent from some sections of the mycorrhizas (Fig. 3). Only some hyphae growing along the surface of the roots were observed. The infection was inter- and intracellular, affecting the outer layers of cortical cells. The epidermis, endodermis and central cylinder were uninfected. Similar features characterized the my- corrhizas formed under gnotoxenic conditions by seedlings of $H$. almeriense inoculated with sporal suspension of $T$. claveryi in an autoclaved soil (CANo et al. 1991).

Inoculation of $T$. claveryi improved in vitro survival of rooted plantlets (Fig. 6). However, this positive effect did not prevent apical necrosis and leaf fall at 6 weeks. This indicates that the MMN medium is not adequate. In comparison with MS medium, MMN is a nutrient-poor medium. Moreover, its high $\mathrm{pH}(8)$ is known to inhibit plant development in vitro (PIERIK 1987).

In conclusion, the results of mycorrhizal synthesis have shown that it is possible to obtain in vitro mycorrhizal symbiosis between micropropagated plantlets of $H$. almeriense and $T$. claveryi on a modified MMN medium. Our further research will concentrate on developing a modified MS medium in order to obtain better plant growth and mycorrhization in vitro, and on studies of post vitro development of mycorrhizal $H$. almeriense plantlets.

Acknowledgements. Maria Asunción Morte acknowledges the receipt of a grant from Spanish Ministerio de Educación y Ciencia. The author thank Kamau Mburu and Tom Smith for improving the English of the paper.

\section{References}

Caboni, E., Boumis, G. \& Damiano, C. 1992. Effects of phenols, gibberelic acid and carbohydrates on the rooting of the apple rootstock M9 Jork. Agronomie 12, 10: 789-794.

Cano, A., Honrubia, M \& Molina-Niñirola, C. 1991. Mycorrhizae in semiarid ecosystems: Synthesis of mycorrhizae between Terfezia claveryi Chat., Picoa juniperi Vit. and Helianthemum almeriense (Cistaceae). $3^{\text {rd }}$ European Symposium on Mycorrhizas, Sheffield, U. K. Abstract book.

Chalupa, V. 1977. Organogenesis in Norway spruce and Douglas fir tissue culture. Commun Institute Forest Technology. 10: 79-87.

CHENG, T.Y. \& VoquI, T. 1977. Regeneration of Douglas fir plantlets through tissue culture. Science 198: 306307.

Fortas, Z. \& Chevalier, G. 1992. Effet des conditions de culture sur la mycorrhization de l'Helianthemum guttatum par trois espèces de terfez des genres Terfezia et Tirmania d'Algérie. Canadian Journal of Botany 70:
2453-2460.

GiovannetTI, M. \& Mosse, B. 1980. An evaluation of techniques for measuring vesicular-arbuscular mycorrhizal infection in roots. New Phytologist 84: 227230.

Honrubia, M., Cano, A. \& Molina-Niñirola, C. 1992. Hypogeous fungi from southern Spanish semi-arid lands. Persoonia, vol. 14, Part 4, 647-653.

MARX, D.H. 1969. The influence of ectotrophic mycorrhizal fungi on the resistence of pine roots to pathogenic infections. I. Antogonism of ectomycorrhizal fungi to root pathogenic fungi and soil bacteria. Phytopathology 59: 153-163.

Moncousin, C., Ribaux, M., Rourke, J.O. \& GavilLET, S. 1992. Effects of type of carbohydrate during proliferation and rooting of microcuttings of Malus Jork. Agronomie 12, 10: 775-782.

MorTe, M.A. \& Honrubia, M. 1992. In vitro propagation of Helianthemum almeriense Pau (Cistaceae). Agronomie 12, 10: 807-809. 
Murashige, T. \& Skoog, F. 1962. A revised medium for rapid growth and bioassays with tobacco tissue culture. Physiologia Plantarum 15: 473-497.

PhILlipS, J.M. \& HaYMAN, D.S. 1970. Improved procedures for clearing roots and staining parasitic and vesicular-arbuscular mycorrhizal fungi for rapid assessment of infection. Transactions of the British Mycological Society 55: 158-161.

PIERIK, R.L.M. 1987. In vitro Culture of Higher Plants. 65 p. and 207 p. 2nd ed. Martinus Nijhoff Publishers, Dordrecht.
Roth-Bejerano, N., Livne, D. \& Kagan-Zur. 1990. Helianthemum-Terfezia relations in different growth media. New Phytologist 114: 235-238.

Timmis, R. \& RitchiE, G.A. 1984. Progress in Douglas fir tissue culture. Proceedings International Symposium Recent Advances Forest Biotechnology, Traverse City, p. $37-46$.

UOSUKAINEN, M. 1992. Rooting and weaning of apple rootstock YP. Agronomie 12, 10: 803-806.

Manuscript received February 1994

\title{
SELOSTUS
}

\section{Terfezia claveryi -sienen in vitro siirrostus mikrolisättyihin Helianthemum almeriense -taimiin}

\author{
Maria Asunción Morte, Antonio Cano, Mario Honrubia ja Pilar Torres \\ Universidad de Murcia, Espanja
}

Terfezia claveryi-sienen ja mikrolisättyjen Helianthemum almeriense-mikrotaimien välistä mykorritsasymbioosia tutkittiin in vitro- olosuhteissa muunnetulla Melin-Norkrans $(\mathrm{MMN})$ agaralustalla, jonka pH oli 8,0. Kahdentoista viikon jälkeen taimien mykorritsaprosentti oli 80. T. claveryi muodosti isäntäkasvin kanssa tupettoman ektendomykorritsan.

Sienen vaikutusta tutkittiin myös in vitro -juurrutukses- sa. $T$. calveryi ei parantanut $H$. almeriense mikropistokkaiden in vitro juurtumista. Mikropistokkaiden eloonjääminen in vitro -olosuhteissa muodostui rajoittavaksi tekijäksi. Mykorritsasiirrostus näytti parantavan juurtuneiden mikrotaimien eloonjäämisprosenttia. Tutkimuksessa pohdittiin myös agaralustan ravinnekoostumuksen ja pH-luvun vaikutusta eloonjäämiseen. 